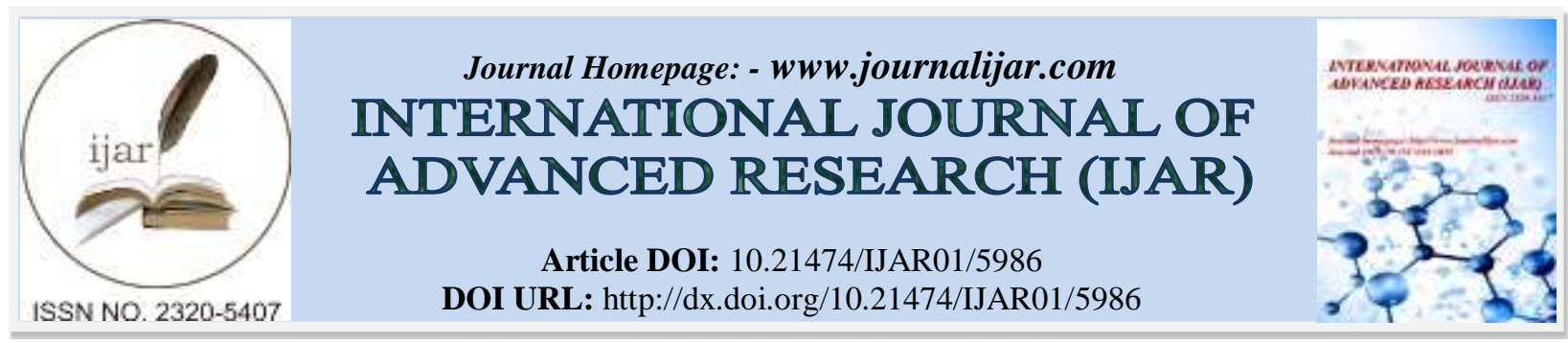

RESEARCH ARTICLE

\title{
TEACHER EFFECTIVENESS OF SECONDARY SCHOOL TEACHERS IN RELATION TO THEIR TEACHING APTITUDE.
}

\author{
Mangalamma H. $S^{1}$ and Dr. S. Vijaya Vardhini ${ }^{2}$. \\ 1. Research Scholar, Dravidian University, Kuppam. \\ 2. Associate Professor, Dravidian University, Kuppam.
}

\section{Manuscript Info}

Manuscript History

Received: 06 October 2017

Final Accepted: 08 November 2017

Published: December 2017

Key words:-

Teacher Effectiveness, Teaching

Aptitude, secondary schools, teachers,

\begin{abstract}
The teacher is most essential in the education field and he/she is the most important pillar in the development of schooling. Teaching aptitude of teacher is a significant issue in teaching and learning progress. The purpose of the study was to find out the relationship between teacher effectiveness and teaching aptitude of teachers. The sample comprised one hundred secondary school teachers working in secondary schools of Bangalore South District selecting by simple random sampling technique. The Teaching Aptitude Scale developed by Dahiya and Singh (2004) and Teacher Effectiveness Scale (2006) developed \& standardized by Umme Kulsum was utilized for data processing. The Pearson's Product Moment Coefficient of Correlation, ' $t$ ' and $F$ Test statistical procedures were applied to examine the formulated hypotheses. The correlation result shows significant relationship between Teacher Effectiveness and Teaching Aptitude of secondary school teachers and from ' $t$ ' and ' $F$ ' test statistical procedures gender and type of school management factors were influences on Effectiveness in Teaching. The female teachers had higher effectiveness in teaching than male teachers and private unaided school teachers had more effective when compared with teachers from private aided and government schools. The study suggests that there should be further focal point on developing aptitude skills among teachers through well supervised practices to improve their teacher effectiveness.
\end{abstract}

Copy Right, IJAR, 2017,. All rights reserved.

\section{Introduction:-}

There are various segments which affect the idea of good training and add to progression of material quality, ability and character of teacher are especially basic. The piece of teachers in moldings commitment of the understudies depends upon the purpose of training. The purpose of instruction at solid is useful, dynamic and unconstrained improvement and progression of identity. A teacher is huge factor in the instructive framework it is fundamental that he/she should have specific capacity and legitimize the commitment of his business. As showed by Great (1959), showing effectiveness as "the level of accomplishment of a teacher in performing instructional and distinctive commitments decided in his distinction and demand by the possibility of his position." "An aptitude is an intrinsic, 
procured, learned or created segment of competency to a specific sort of work at a specific level." aptitude infers innate limit with regards to getting the hang of, comprehension or performing.

An aptitude is a piece of a competency to do a particular kind of work at a particular level, which can in like manner be considered 'ability.' Aptitude is a trademark ability to fulfill something. Showing aptitude is a specific limit, plausibility, interest, satisfaction and health in educating calling. Showing Aptitude is capacity to secure ability or mastery with a given measure of getting ready. Showing Aptitude is basic for the teachers to do their occupation viably and can play out his commitment fittingly. It is one of the critical determinants of teacher effectiveness. Bhasin (1988) contemplated that showing aptitude had no quick relationship with teacher assemble participation. Kahlon and Saini (1989) found that instructing of training courses affect the change of educating aptitude. Victor (2012) presumes that female teacher have more showing aptitude than their accomplice male teachers. Seetharaman (2013) presumes that teacher effectiveness and showing aptitude are sure and on a very basic level related.

\section{Need And Importance Of The Study:-}

Teacher is the crucial stage amid the time spent for education and training. If he/she is capable, genuine, dedicated individual we can be ensured of the nation's future is in their grasp to make great resident. A teacher should have constructive aptitude to deal with the students and to awaken them to touch the statures of human development and to be reliable nationals of the country and moreover awesome individual to serve the overall population in bona fide way. The execution of teacher is unforeseen, in a manner of speaking, on his aptitudes and affirmation. The aptitude of teacher impacts the execution and furthermore direct of the substitute. The idea of teacher training can be upgraded by various techniques viz., improving the instructive projects, upgrading the work on educating etcetera as it might, the most fundamental one is from every angle the aptitude in instructing. Along these lines, in teacher training program it is critical to give adequate noteworthiness to showing aptitude of secondary school teachers. Henceforth to choose secondary school teachers for teacher training establishments it is basic to have an aptitude test. In this way, the showing aptitude makes the fast approaching teachers instruct feasibly with uncommon power and impressiveness. Thusly, in light of a true blue worry for a huge and making instructive structure for the country, it is huge that the assurance of the teachers should be made on the commence of their educating aptitude. In case the charming credits are to be made in arranged teachers, they require aptitude for these qualities. Without the aptitude, these qualities may not be made to the required levels. In this manner, showing aptitude is a fundamental basic for effective instructing. The inspiration driving the examination is to know the relationship between Teacher Effectiveness of secondary teachers and their Teaching Aptitude and moreover find effect of few variables on the Teacher Effectiveness.

\section{Objectives:-}

1. To realize the teacher effectiveness of secondary school teachers.

2. To assess the teaching aptitude of teachers.

3. To expose the significant relationship between teacher effectiveness and teaching aptitude of teachers.

4. To discover the significant difference of teachers in their teacher effectiveness due to gender and type of institution.

\section{Statement Of Hypotheses:-}

1. There exists significant relationship between Teacher Effectiveness and Teaching Aptitude of secondary school teachers.

2. There exists significant difference in the Teacher Effectiveness of secondary school teachers with reference to their gender and type of institution.

\section{Methodology :-}

The study was elected as descriptive survey method. The secondary school teachers comprised as the population of the study. The sample comprised one hundred secondary school teachers served in secondary schools in Bangalore South District, Karnataka by utilizing simple random sampling technique. The researcher selected two scales namely Teacher Effectiveness Scale (2006) developed \& standardized by Kulsum and Teaching Aptitude Test by Dahiya and Singh (2004) which were employed to collect the information. The collected data was analyzed by utilizing appropriate statistical techniques namely percentage, mean, standard deviation, Correlation, independent ' $t$ ', ' $F$ ' Tests and Scheffe's Post Hoc test. 


\section{Results Of The Study:-}

Table-1:- Levels of Teacher Effectiveness.

\begin{tabular}{|l|c|c|c|}
\hline \multicolumn{1}{|c|}{ Teacher Effectiveness } & N & Percentage & $\begin{array}{c}\text { Cumulative } \\
\text { Percentage }\end{array}$ \\
\hline Ineffective & 18 & $18.0 \%$ & $18.0 \%$ \\
\hline Average & 77 & $77.0 \%$ & $95.0 \%$ \\
\hline Effective & 5 & $5.0 \%$ & $100.0 \%$ \\
\hline
\end{tabular}

The table-1 illustrates that $5.00 \%$ teachers expressed effective in teaching and 77 teachers uttered average and only 18 teachers demonstrate ineffective in teaching.

Table-2:- Levels of Teaching Aptitude

\begin{tabular}{|l|c|c|c|}
\hline \multicolumn{1}{|c|}{ Teaching Aptitude } & N & Percentage & $\begin{array}{c}\text { Cumulative } \\
\text { Percentage }\end{array}$ \\
\hline Good & 8 & $8.0 \%$ & $8.0 \%$ \\
\hline Average & 79 & $79.0 \%$ & $87.0 \%$ \\
\hline Poor & 13 & $13.0 \%$ & $100.0 \mid \%$ \\
\hline
\end{tabular}

The table- 2 demonstrates $79.00 \%$ teachers articulated average aptitude in teaching, $8.00 \%$ teachers were uttered good aptitude and only 13 teachers expressed poor aptitude level in teaching.

Table-3:- Results pertaining to Correlation analysis pertaining to teacher effectiveness and teaching aptitude.

\begin{tabular}{|c|c|c|}
\hline Dependent & Independent & 'r' value and Sig. Level \\
\hline Teacher Effectiveness & Teaching Aptitude & $0.462^{* *}$ \\
\hline
\end{tabular}

$\mathrm{N}=100 ; \mathrm{df}=98 ; \mathrm{r}$ value @ $0.01=0.254$.

From the table- 3 revealed that, the obtained ' $r$ ' value 0.462 is greater than the table value 0.254 at 0.01 level of confidence. Therefore, the stated hypothesis "there exists significant relationship between Teacher Effectiveness and Teaching Aptitude of secondary school teachers" was accepted. The selected variables are having positive relationship. The result concludes that teachers had higher level of teaching aptitude had better teacher effectiveness and in a vice versa.

Table-4:- Teacher Effectiveness of secondary school teachers due to variation in their gender

\begin{tabular}{|c|l|c|c|c|c|}
\hline \multirow{2}{*}{ Variable } & \multicolumn{1}{|c|}{ Groups } & No. & Mean Scores & $\begin{array}{c}\text { Standard } \\
\text { Deviation }\end{array}$ & $\begin{array}{c}\text { 't' value and } \\
\text { sig. level }\end{array}$ \\
\hline \multirow{2}{*}{ Gender } & Male & 26 & 329.307 & 80.791 & \multirow{2}{*}{$3.25^{* *}$} \\
\cline { 2 - 5 } & Female & 74 & 393.567 & 101.122 & \\
\hline
\end{tabular}

$* *$ Significant at 0.01 level.

It is evident from Table-4, the obtained ' $t$ ' value 3.25 is greater than table value 2.63 at 0.01 level of confidence. Hence, the stated hypothesis for the said variable is accepted that is there exists significant difference in the Teacher Effectiveness between male and female teachers. The female teachers had more effective when compared with male teachers in effectiveness of teaching. 


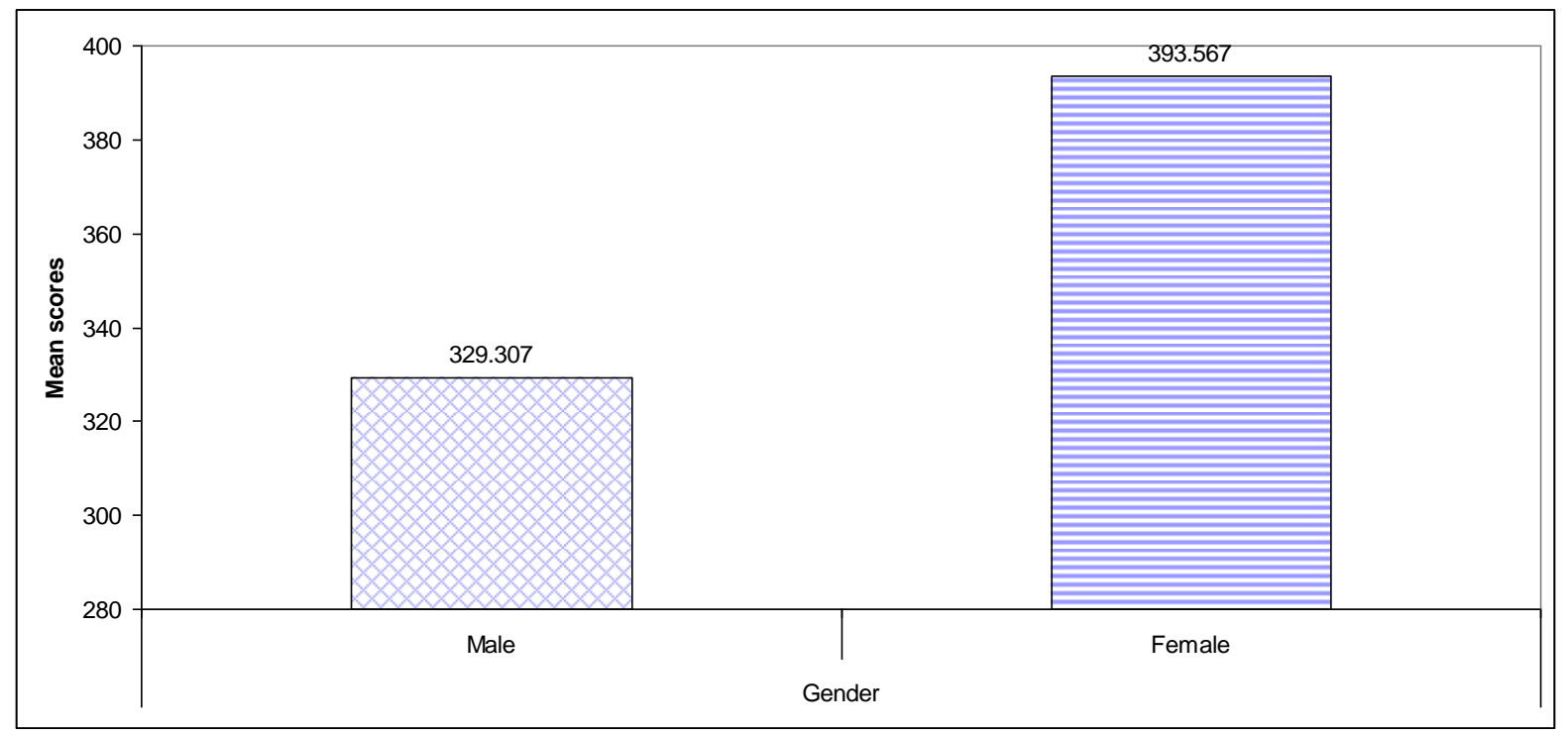

Fig.1:- Bar graph shows comparison of teacher effectiveness between male and female teachers

Table-5:- Teacher Effectiveness due to variation in type of institution.

\begin{tabular}{|c|c|c|c|c|c|c|c|c|}
\hline Group & $\mathbf{N}$ & Mean & SD & Source & $\begin{array}{c}\text { Sum of } \\
\text { Squares }\end{array}$ & df & $\begin{array}{c}\text { Mean } \\
\text { Squares }\end{array}$ & $\begin{array}{c}\text { F Value } \\
\text { (Sig.) }\end{array}$ \\
\hline Govt. & 30 & 302.300 & 84.828 & $\begin{array}{l}\text { Between } \\
\text { Group }\end{array}$ & 276627.17 & 2 & 138313.584 & \multirow[t]{3}{*}{18.83} \\
\hline Private Aided & 35 & 385.400 & 77.702 & $\begin{array}{l}\text { Within } \\
\text { Group }\end{array}$ & 712490.87 & 97 & 7345.267 & \\
\hline Private Unaided & 35 & 432.228 & 93.703 & Total & 989118.04 & 99 & & \\
\hline
\end{tabular}

Table value at $0.05(\mathrm{df}-2,97)=3.09$; Table value at $0.01(\mathrm{df}-2,97)=4.82$

The table- 5 shows that, the obtained ' $F$ ' value 18.83 is greater than the table value of 4.82 for $\mathrm{df}$ ' 2 and 97 ' requested for significance at 0.01 level of significance. The results of the study indicated that "there exists significant difference in the Teacher Effectiveness of secondary school teachers working in government, private aided and private unaided schools. To determine the significant difference in the teacher effectiveness among these paired mean scores, the 'Scheffe's post hoc test was applied and the results are presented in Table-5(a).

Table-5(a):- Scheffe's Post Hoc Analysis on Teacher Effectiveness scores of teachers working in different type of institution.

\begin{tabular}{|c|c|c|c|}
\hline \multicolumn{3}{|c|}{ Type of Institution } & \multirow{2}{*}{ Mean Difference } \\
\hline Government & Private Aided & Private Unaided & \\
\hline 302.300 & 385.400 & - & $83.100^{*}$ \\
\hline- & 385.400 & 432.228 & 46.828 \\
\hline 302.300 & - & 432.228 & $129.928^{*}$ \\
\hline
\end{tabular}

*Significant at 0.05 level.

Table-5(a) shows significant paired mean differences in the teacher effectiveness between government and private aided; government and private unaided and the mean differences are 83.100 and 129.928 which are greater than the critical difference value. It concludes that "there exists significant difference in the teacher effectiveness between teachers working in government and private aided; government and private unaided schools. The teacher effectiveness of private aided and private unaided school teachers had similar and it was not proved statistically, since the mean difference 46.828 is less than the value of critical difference. The private unaided teachers had more effective when compared with private aided and government school teachers. 


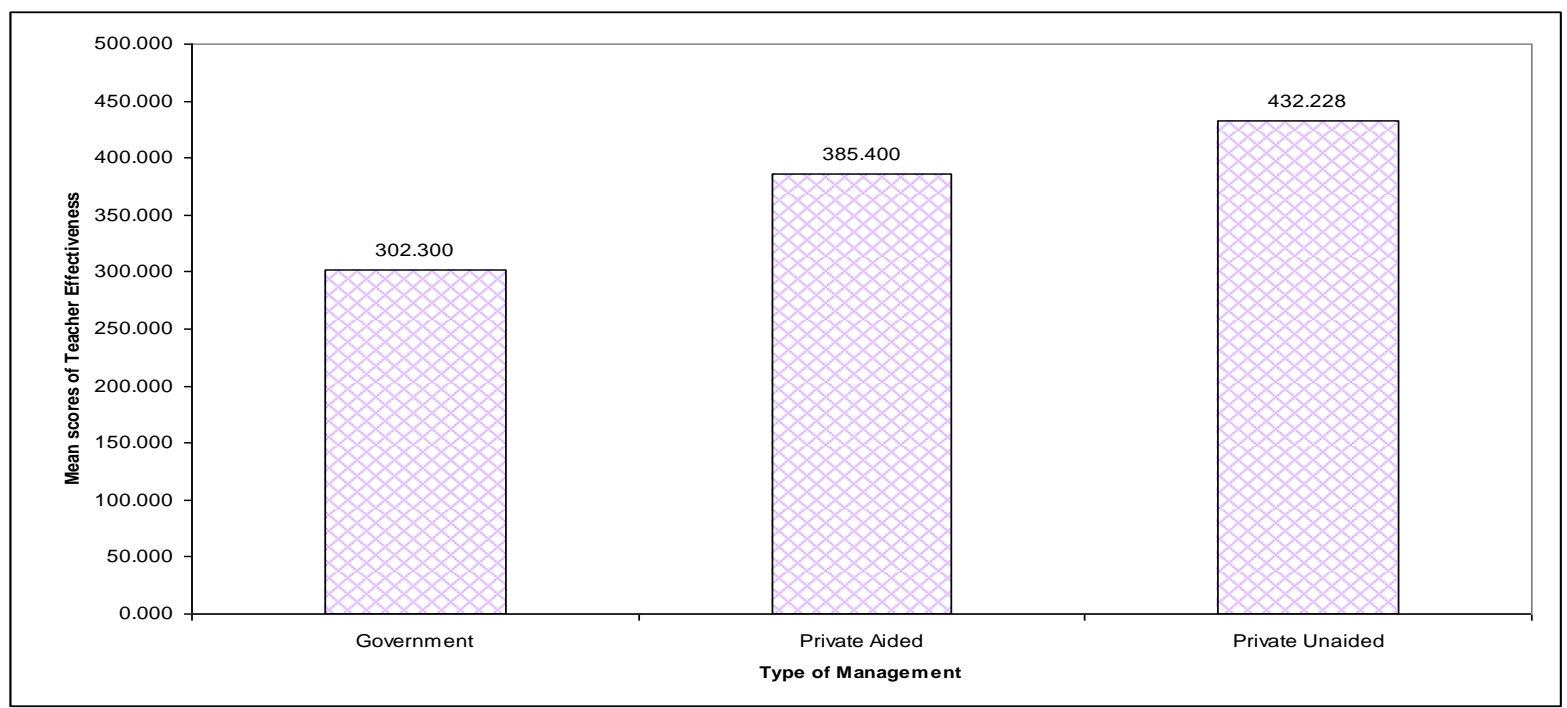

Fig.2:- Bar graph shows comparison of teacher effectiveness among teachers working in different type of institution.

\section{Major Findings Of The Study:-}

1. There exists significant relationship between Teacher Effectiveness and Teaching Aptitude of teachers.

2. There exists significant difference in the Teacher Effectiveness of male and female teachers.

3. There exists significant difference in the Teacher Effectiveness of teachers working in different type of school management.

\section{Conclusion:-}

From the present investigation it was demonstrates that, teachers' aptitude towards teaching was positively related with their teacher effectiveness. Teaching Aptitude and Teacher Effectiveness are connected with each other. The present investigation exposes that aptitude enhances effectiveness of teaching. The study additionally found from the ' $t$ ' test analysis that there exists significant contrast in the teacher effectiveness of secondary school teachers regarding gender and from the ' $F$ ' test analysis it was also found significant difference in the teacher effectiveness of secondary school teachers regarding type of management. The effectiveness and aptitude of teachers are in average level. It is essential that integration information programmes and exercises to be conducted to improve teacher effectiveness and additionally realistic introduction programmes and differential Aptitude tests for preparing programme, career guidance programmes are to be organized to upgrade teaching aptitude. Workshops, refresher courses and seminars ought to be escalating for the teachers as fundamental to keep them equivalent to information in their respective subjects.

\section{References:-}

1. Babu, K.B. and Rao, D.B.(2007). Teaching Aptitude of Primary School Teachers. Sonali Publications: New Dehli.

2. Bhasin, C. (1988). Teaching Aptitude and its relationship with teaching effectiveness of the Higher Secondary

3. Good, C.V. (1959).Dictionary of Education New York: McGraw Hill Book Co.

4. Kahlon, S.P. and Saini, S.K.(1989). Impact of Teacher Education on Teaching Aptitude. Punjab Agricultural University, Education Graduals, Punjab.

5. Pandya, R.K.(1993). A study of teaching aptitude of secondary school teachers of Gujarat State in the context of some psychological variables. Ph.D., Edu., Sardar Patel University.

6. Samson. R. Victor Aptitude And Academic Training For Teacher Development In Elt, International Journal Of Behavioral Social And Movement Sciences, April 2012, Vol.01 (2): 117-124.

7. Schools Teachers in relation to the Modern Community. Ph.D, Edu., Rani Durgawati Vishwavidyalaya.

8. Seetharaman "Teaching Effectiveness of B.Ed Student Teachers as Related to their Teaching Aptitude and Academic Performance" International Journal of Teacher Educational Research (IJTER) September, 2013, Vol.2:(9): 10-19. 